\section{$1: 76$}

膜症の場合ミクロアノイリスマが直像鏡では見えるが, 写真にはうつらない場合がある様で, 未だ両検查の併用 が必要であると思らが如何。

答：新井宏明（千大 公衛） (1) $6 \times 6 \mathrm{~cm}$ レントゲン フィルムによる眼底撮影の現像は胸部レ線撮影と同様に 扣こないました。

解像力, コントラストは $35 \mathrm{~mm}$ フィルム（ミニコピ 一，F級）よりすぐれていると执すいます。

(2) 現在の眼底カメラは Microaneurysma もかなり よく撮影されると考光ます. 直像鏡とカメラの併用につ いて，カメラにより Screening した異常者を更に直像 鏡にて精検する方式がよいと招もいすす。

\section{2. 眼底の各種老年性変化, 特に網膜血管の 老年性変化に関する眼底撮影による追跡 的研究 (予報) \\ 桑原安治 ○松井瑞夫 \\ (慶応大学 眼科)}

眼底撮影による老年性変化の追跡的研究の第一歩とし $\tau, 2,3$ の眼底変化につき, 眼底撮影々検眼鏡による所 見把握の効率につき比較検討を行った。
1 巻 1 号 (1964: 4)

循環器集団検診の際に，300 名につき眼底撮影を行い， 高血圧性眼底変化について検討を行った。高血圧性眼底 病変のらち, 軽度の動脈狭細, 口径動摇等は, 眼底写真 撮影の方が，所見把握の点ですぐれている。また，細動 脈硬化では，検眼鏡と写真撮影による判定との飡違いは 非常に少い。

このように, 軽度の動脈狭細, 口径動摇等も写真にて 充分把握しうるので，血管の老年性变化の追及に充分使 用しうるので，血管の老年性変化の追及に充分使用しう ると考える。

次に網膜黄斑部の病变を写真にて把握しうるや否やを 検討するため, 溶鉱炉と前作業者 131 名につき眼底撮影 を行った。 その結果, 黄斑部の微細な病変も写真にて把 握しうることが知られた。

老人になると次第に消褪するとされている網膜反射に ついて検討を行った．網膜反射の程度をH，十, 一と 3 段階に分けて年令との関連性をみると, 明らかな関連性 がみられた。

以上の如 $<$, 血管変化, 黄斑部変化, 網膜反射につい ては, 検眼鏡によると略々同等の効率で, 眼底写真によ り所見の把握が可能であることが知られた。

\title{
訂正
}

昭和 38 年度発行, 第 4 回日本老年医学会総会討議記録に下記の誤りがあり

ましたので，訂正いたします。

\begin{tabular}{c|cc|c|c}
\hline ページ & 行 & 数 & 誤 & 正 \\
\hline 31 & 1 段目下から 9 & 眻病率は人口 10 万対 400 & 罹病率は人口 10 万対 383 \\
171 & 2 段目下から $15 \sim 16$ & ‥鈴木恵子 & 小倉剛 $\cdots$ & …鉿木恵子 塚本望 小倉剛 $\cdots$ \\
\hline
\end{tabular}

